\title{
Tuzların hidrolizi konusunun öğretiminde argümantasyon tabanlı bilim öğrenme (atbö) yaklaşımının etkisi
}

\author{
The effect of argumentation-based science learning (absl) on the teaching of salt \\ hydrolysis
}

Gonca HARMAN*
Dilek ÇELIKLER ${ }^{\star *}$

\begin{abstract}
Öz
$\mathrm{Bu}$ araştırmada tuzların hidrolizi konusunun öğretiminde АTBÖ yaklaşımının öğrenme, kavram yanılgılarının belirlenmesi ve giderilmesi üzerindeki etkisi incelenmiştir. Araştırmaya fen bilgisi eğitimi anabilim dalı birinci sınıfta öğrenim gören 45 öğretmen adayı katılmıştır. Araştırmada tek örneklem ön test - son test desen kullanılmıştır. Çalışma yaprakları uygulama öncesi ön test, uygulama sonrası son test şeklinde uygulanarak veriler toplanmıştır. Araştırmada sodyum asetat, kalsiyum nitrat ve amonyum klorür tuzlarının asidik, nötr ya da bazik olma durumları sorgulanmıştır. Deneysel etkinlik sırasında doldurmaları için öğretmen adaylarına ATBÖ öğrenci şablonu verilmiştir. Uygulama sonunda öğretmen adaylarından ATBÖ yaklaşımına ilişkin düşüncelerini ifade etmeleri istenmiştir. Araştırma sonucunda ATBÖ yaklaşımının tuzların hidrolizi konusunu öğrenme ile kavram yanılgılarının belirlenmesi ve giderilmesi üzerinde etkili olduğu saptanmıştır. Öğretmen adaylarının ATBÖ yaklaşımına yönelik olumlu düşüncelerini ön bilgileri açığa çıkarma ve yeni öğrenilen bilgilerle karşılaştırma; anlamlı, kalıcı, kolay ve eğlenceli öğrenmeyi sağlama; tartışma ve fikir alışverişleri ile grup etkinliklerine katılım; raporu aşama aşama ve bilinçli yazma ve deneyi farkında olarak yapma şeklinde ifade ettikleri belirlenmiştir. Az sayıda öğretmen adayının ise uygulamanın uzun sürdügünü ve zor deneylerde uygulanmasının güç olduğunu düşündüğü saptanmıştır.
\end{abstract}

Anahtar Kelimeler: ATBÖ, tuzların hidrolizi, fen bilgisi öğretmen adayı.

\footnotetext{
Abstract

This study investigated the effect of the ABSL approach on the learning of salt hydrolysis, and identifying and remedying misconceptions. The study was conducted with the participation

** Doç. Dr., Ondokuz Mayıs Üniversitesi, Eğitim Fakültesi, İlköğretim Fen Bilgisi Eğitimi ABD.,
}

* Dr., e-posta: goncaharman@hotmail.com e-posta: dilekc@omu.edu.tr 
of 45 first-year teacher candidates attending the science education department of a faculty of education in Turkey, and was performed based on a pretest-posttest design, in that data collection was carried out both before the study methods were applied (pretest) and after (posttest). In this study, participants were asked whether sodium acetate, calcium nitrate and ammonium chloride salts are acidic, neutral or basic. During the experiment-based activities of the study, teacher candidates were given an ABSL template. At the end of the study, teacher candidates were asked to express their thoughts about the ABSL approach. Study results indicated that the ABSL approach was effective in the learning of salt hydrolysis, and identifying and remedying misconceptions on this subject. Positive aspects described by the teacher candidates regarding the ABSL approach included its ability to reveal students' preliminary knowledge on a subject; allow students to compare their initial and new knowledge on a given subject; ensure meaningful, lasting, easier and entertaining learning; allow group activities and interactions that promote discussion and the exchange of ideas; enable reports to be written stage by stage in a more knowledgeable manner; and allow experiments to be conducted with a greater level of awareness. On the other hand, a small number of teacher candidates described that the method required too much time, and it is rather difficult to implement for complex experiments.

Keywords: ABLS, salt hydrolysis, science teacher candidates.

\section{Giriş}

ATBÖ öğrencilere başlangıç soruları, açıklamalar, test, iddia ve kendi iddiaları için oluşturdukları kanıtlar üzerine yaptıkları küçük ve büyük tartışmalarda fen kavramlarını anlama ve anlamlandırmada yardımcı olan bir yaklaşımdır (Kabataş-Memiş, 2014). Bu yaklaşım öğrencilerin kavramları aktif olarak, laboratuvarda araştırma yaparak kavramsal öğrenmeyi gerçekleştirmesi için kullanılan araştırma sorgulamayı temele almaktadır (Hand ve Keys, 1999; Akt: Kabataş-Memiş, 2014; Keys, Hand, Prain ve Collins, 1999). Yaklaşımın temelini oluşturan argümanlar Toulmin (1958) tarafından ifade edilen veri, iddia, gerekçe, destekleyici, sınırlayıcı ve çürütme olmak üzere 6 öğeyi kapsayacak şekilde oluşturulmaktadır. Toulmin’in modelindeki 6 öğe Driver, Newton ve Osborne (2000) tarafından açıklamıştır. Buna göre;

- Veri iddiayı desteklemek ve daha açık hale getirmek için oluşturulan ifadedir.

- İddia mevcut görüşlerin ortaya koyulmasıdır.

- Gerekçe veri ve iddia arasındaki ilişkileri açıklayan nedendir.

- Sınırlayıcı iddianın doğru olarak kabul edilebileceği koşulları belirler.

- Destekleyici varsayımın kabul edilebilirliğini destekler.

- Çürütme iddianın doğru olamayacağı durumları belirler.

ATBÖ yaklaşımı öğretmen ve öğrencilere rehber olacak 2 şablon içermektedir. Öğretmen için olan şablon dersleri ATBÖ’ ye uygun olacak şekilde planlamada; öğrenci şablonu ise hem araştırma-sorgulamaya dayalı etkinliklerde hem de rapor yazmada yol göstericidir (Hand, Wallace, ve Yang, 2004; Keys vd., 1999). 
Tuzların hidrolizi konusunun öğretiminde argümantasyon tabanlı bilim öğrenme (atbö) yaklaşımının etkisi

\section{ATBÖ öğretmen şablonu}

1. Kavram haritası kullanılarak ön bilgilerin açı̆̆a çıkarılması

2. İnformal yazma, gözlem yapma, beyin fırtınası ve soru sorma teknikleri kullanılarak laboratuvar uygulamaları öncesinde etkinliklerin yapılması

3. Laboratuvar etkinliklerine aktif olarak katılımın sağlanması

4. I. Müzakere Fazı - laboratuvar etkinliklerinde bireysel yazma etkinliklerinin yapılması (Örneğin; günlük yazma)

5. II. Müzakere Fazı - küçük gruplarda gözlemler sonucunda elde edilen verilerin yorumlarının paylaşılması ve kıyaslanması (Örneğin; grup olarak taslak oluşturma)

6. III. Müzakere Fazı - düşüncelerin kitap ya da diğer kaynaklar ile karşılaştırılması (Örneğin; başlangıç sorularını cevaplandırmaya yönelik grup notu çıkarma)

7. IV. Müzakere Fazı - bireysel yansıma ve yazma etkinliklerinin yapılması (Örneğin; bilgi verilecek kişiler için rapor ya da poster gibi sunum hazırlama)

8. Kavram haritası kullanılarak öğretim sonunda öğrenilen bilgilerin açığa çıkarılması

\section{ATBÖ öğrenci şablonu}

1. Başlangıç Düşünceleri - Sorularım nelerdir?

2. Testler - Ne yaptım?

3. Gözlemler - Ne gördüm?

4. İddialar - Ne iddia edebilirim?

5. Kanıt - Nasıl anladım? Niçin bu iddialarda bulunuyorum?

6. Okuma - Benim düşüncelerim başka düşüncelerle nasıl karşılaştırılır?

7. Yansıma - Düşüncelerim nasıl değiști?

Alanyazın incelendiğinde ilk (Öğreten ve Uluçınar-Sağır, 2014; McNeill, 2011) ve ortaokul öğrencileri (Alexopoulou ve Driver, 1996; Bell ve Linn, 2000; Çinici vd., 2014; Deveci, 2009; Günel, Kabataş-Memiş ve Büyükkasap, 2010; Hand vd., 2004; Hohenshell ve Hand, 2006; KabataşMemiş, Günel ve Büyükkasap, 2009; Kabataş-Memiş, 2014; Khishfe, 2014; Türkoğuz ve Cin, 2013; Uluçınar-Sağır ve Kılıç, 2013; Üstünkaya ve Savran-Gencer, 2012; Yeşildağ-Hasançebi ve Günel, 2013), lise öğrencileri (Grimberg ve Hand, 2003; Kıngır, Geban ve Günel, 2011; McNeill ve Pimentel, 2010; Yeşiloğlu, 2007), organik kimya bölümünde öğrenim gören üniversite öğrencileri (Hand ve Choi, 2010), fen bilgisi öğretmen adayları (Akar, Erkol, Kabataş, Büyükkasap ve Günel, 2007; Çetin, 2014; Demirbağ ve Günel, 2014), kimya öğretmen adayları (Tümay ve Köseoğlu, 2011), biyoloji öğretmen adayları (Ceylan, 2010), öğretmen adayları (Kaya, 2013), ilk, orta ve lise öğretmenleri (McNeill ve Knight, 2013), fen bilgisi öğretmenleri (Newton, Driver ve Osborne, 1999; Osborne, Erduran ve Simon, 2004) olmak üzere farklı örneklemlerde fen konularına 
yönelik argümantasyona dayalı uygulamaların etkilerinin incelendiği çeşitli araştırmaların olduğu görülmektedir. Bu araştırmalarda argümantasyona dayalı uygulamaların akademik başarı (Akar vd., 2007; Demirbağ ve Günel, 2014; Hand ve Choi, 2010) ve öğrenme (Çetin, 2014; Kaya, 2013; McNeill ve Knight, 2013; Newton vd., 1999; Osborne vd., 2004; Tümay ve Köseoğlu, 2011) üzerinde olumlu etkilerinin olduğu ortaya koyulmuştur. Argümantasyona dayalı uygulamaların kavramsal anlamanın arttırılması (Türkoğuz ve Cin, 2013; Üstünkaya ve Savran-Gencer, 2012; Yeşildağ-Hasançebi ve Günel, 2013), kavramsal değişimin gerçekleştirilmesi (Tümay ve Köseoğlu, 2011) ve kavram yanılgılarının giderilmesi (Alexopoulou ve Driver, 1996; Bell ve Linn, 2000; Yeşiloğlu, 2007) üzerinde olumlu etkilerinin olduğu saptanmıştır. Argümantasyona dayalı uygulamaların bilimsel düşünme (Akkus, Gunel ve Hand, 2007; Cavagnetto, 2010; Duschl ve Osborne, 2002; Grimberg ve Hand, 2003; Lawson, 2003; Tümay ve Köseoğlu, 2011), sorgulama (Tümay ve Köseoğlu, 2011) ve tartışma becerilerine (Öğreten ve Uluçınar-Sağır, 2014) olumlu katkılar sağladığı belirlenmiştir. Argümantasyona dayalı uygulamaların argüman kurma ve yazma becerileri ile (Demirbağ ve Günel, 2014) bilimsel okuryazarlığın gelişimini desteklediği ortaya koyulmuştur (Deveci, 2009; Driver vd., 2000; Hand vd., 2004; Norris ve Philps, 2003; Köseoğlu, Tümay ve Budak, 2008; Uluçınar-Sağır ve Kılıç, 2013). Ayrıca bilimin doğası ile ilgili anlayışları geliştirerek (Tümay ve Köseoğlu, 2011) bilimin doğasını anlamayı sağladığı, muhakeme ve araştırma yeteneklerini geliştirdiği, eleştirel düşünme becerilerini arttırdığı saptanmıştır (Çetin, 2014; Kaya, 2013; Khishfe, 2014; McNeill ve Pimentel, 2010; McNeill, 2011; McNeill ve Knight, 2013; Newton vd., 1999; Osborne vd., 2004). Argümantasyona dayalı uygulamaların sorumluluk duygusunun kazandırılması, özgüvenin arttırılması (Kabataş-Memiş, 2014) ve öz değerlendirme yapabilme (Demirbağ ve Günel, 2014) üzerinde olumlu etkileri olduğu belirlenmiştir.

$\mathrm{Bu}$ uygulamalar verimli bir öğrenme ortamı oluşturarak öğrencilerin sosyalleşmelerine imkân sunup öğrenme sürecini öğrenci merkezli yaparak hem öğrenci hem de öğretmen adına daha eğlenceli bir öğrenme-öğretme ortamı sağlamaktadır (Yeşildağ-Hasançebi ve Günel, 2013). Böyle bir öğrenme ortamından öğrenciler hoşlanmakta (Çinici vd., 2014) derse karşı ilgileri ve katılımları artmaktadır (Tümay ve Köseoğlu, 2011). Bu durum da öğrencinin derse yönelik tutumu üzerinde olumlu etki oluşturmaktadır (Akar vd., 2007; Ceylan, 2010; Demirbağ ve Günel, 2014; Günel vd., 2010; Hohenshell ve Hand, 2006; Kabataş-Memiş vd., 2009; Kıngır vd., 2011). $\mathrm{Bu}$ olumlu sonuçların beraberinde argümantasyona dayalı uygulamaların yapıldığı öğrenciler derslerde sıklıkla bu tür etkinliklerin yapılması gerektiğini ifade etmektedir (Kabataş-Memiş, 2014).

$\mathrm{Bu}$ araştırma ile alanyazında ifade edilen tüm bu pozitif etkiler ışı̆̆ında kimyanın temel konularından biri olan tuzların hidrolizi konusunun öğretiminde АТВÖ yaklaşımının öğrenme, kavram yanılgılarının belirlenmesi ve giderilmesi üzerindeki etkisini belirlemek amaçlanmıştır.

$\mathrm{Bu}$ araştırma ile aşağıdaki sorulara cevap aranmıştır.

1-Tuzların hidrolizi konusunun öğretiminde kullanılan АТВÖ yaklaşımının öğrenme üzerinde nasıl bir etkisi vardır? 
Tuzların hidrolizi konusunun öğretiminde argümantasyon tabanlı bilim öğrenme (atbö) yaklaşımının etkisi

2-Tuzların hidrolizi konusunun öğretiminde kullanılan ATBÖ yaklaşımının kavram yanılgılarının belirlenmesi üzerinde nasıl bir etkisi vardır?

3-Tuzların hidrolizi konusunun öğretiminde kullanılan ATBÖ yaklaşımının kavram yanılgılarının giderilmesi üzerinde nasıl bir etkisi vardır?

\section{Yöntem}

\section{Araştırmanın deseni}

Araştırma tek örneklem ön test-son test desenine uygun olarak gerçekleştirilmiştir.

\section{Araştırmanın katılımcı grubu}

Araştırma fen bilgisi eğitimi anabilim dalı birinci sınıfta öğrenim gören 45 öğretmen adayının katılımı ile gerçekleştirilmiştir.

\section{Veri toplama aracı}

Araştırmada veri toplama aracı olarak çalışma yaprağı ve yarı yapılandırılmış görüşme formu kullanılmıştır.

Çalışma yaprağı sodyum asetat, kalsiyum nitrat ve amonyum klorür tuzlarının asidik, nötr ya da bazik olma durumlarının sorgulandığı üç açık uçlu sorudan oluşmaktadır. Veri toplama aracında yer alan soruların kapsam geçerliğinin yeterli olup olmadığını, gereksiz, düzeltilmesi gereken ya da anlaşılmayan herhangi bir ifade olup olmadığını saptamak amacıyla uzmanlık alanı kimya eğitimi ve fen bilgisi eğitimi olan iki öğretim üyesinden görüş alınmıştır. Veri toplama aracında yer alan soruların anlaşılırlığını ve uygulama süresini belirlemek amacıyla pilot uygulama yapılmıştır.

Yarı yapılandırılmış görüşme formunda ise "ATBÖ yaklaşımına yönelik düşüncelerinizi ifade ediniz." sorusu yer almıştır.

\section{Uygulama süreci}

Araştırma Genel Kimya Laboratuvarı II dersi kapsamında ATBÖ yaklaşımına uygun olacak şekilde 4 ders saatinde gerçekleştirilmiştir. Laboratuvarda gerçekleştirilen uygulamanın verimli olabilmesi için 45 öğretmen adayı 23 (grup 1) ve 22 (grup 2) kişilik iki ayrı gruba ayrılmıştır. İki grupta da araştırmacılar tarafından aynı uygulama gerçekleştirilmiştir.

Konuya ilişkin ön bilgileri ortaya çıkarabilmek için kavram karikatürleri kullanılarak hazırlanan çalışma yaprağı öğretmen adaylarına ön test olarak uygulanmıştır.

Laboratuvar öncesi etkinliklerde beyin fırtınası ve soru-cevap tekniği kullanılmıştır. Laboratuvar etkinliği kapsamında ise tuzların hidrolizi konulu deney yapılmış ve deneyle eş zamanlı olarak gerçekleştirilen bireysel yazma faaliyetlerinde araştırmaya katılan her öğretmen adayı ATBÖ öğrenci şablonunu doldurmuştur. 
Öğretmen adayları 2-3 kişilik gruplar halinde deneysel etkinliği yapmış, gözlemlerinden elde ettikleri verileri yorumlayarak birbirleri ile paylaşmış ve aralarında kıyaslamışlardır. Daha sonra başlangıç düşüncelerini laboratuvarda gerçekleştirilen deneysel etkinlikler için takip edilen kaynak kitapla karşılaştırmışlardır. Öğretmen adayları düşüncelerindeki değişimi ortaya koyabilmek için deneyin başlangıcındaki düşünceleri ile sonucundaki düşüncelerini karşılaştırmışlardır. Uygulamanın sonunda ATBÖ yaklaşımının öğrenme, kavram yanılgılarının belirlenmesi ve giderilmesi üzerindeki etkilerini saptamak için kavram karikatürleri kullanılarak hazırlanan çalışma yaprağı öğretmen adaylarına son test olarak uygulanmıştır.

Ayrıca uygulama sonunda öğretmen adaylarının ATBÖ yaklaşımına yönelik düşüncelerini saptamak amacı ile gönüllü olan 17 öğretmen adayı ile yarı yapılandırılmış görüşme yapılmıştır.

\section{Verilerin analizi}

Fen bilgisi öğretmen adaylarının oluşturdukları argümanlar Venville ve Dawson (2010) tarafından geliştirilen kriterler dikkate alınarak puanlandırılmıștır. Bu kriterlere göre, argümanlar 1 ile 4 arasında kategorilere ayrılmıştır. Buna göre en zayıf argüman 1, en güçlü ya da en nitelikli argüman ise 4 . seviyeye karşılık gelmektedir (Tablo 1).

Tablo I

Argümanın Niteliği ve Değerlendirildiği Seviye

\begin{tabular}{|c|c|}
\hline Argümanın niteliği & Seviye \\
\hline İddia & 1 \\
\hline İddia, veri ve/ya da gerekçe & 2 \\
\hline İddia, veri/gerekçe ve destek ya da niteleyici & 3 \\
\hline İddia, veri/gerekçe, destek ve niteleyici & 4 \\
\hline
\end{tabular}

Öğretmen adaylarının oluşturdukları argümanlara sırasılyla seviyelerine göre 1, 2, 3 ve 4 puan, yanlış cevaplar ile boş bırakılan sorulara ise 0 puan verilmiştir. Araştırmadan elde edilen bu nicel verilerin analizi SPSS paket programı kullanılarak yapılmıştır. Nitel veriler ise betimsel analiz yöntemi kullanılarak analiz edilmiştir. Nitel veriler birbirinden bağımsız iki araştırmacı tarafından analiz edilmiş ve analiz sonuçları karşılaştırılmıştır. Verilerin ham hali ile analiz edilmiş hali bir uzman tarafından da incelenmiştir.

\section{Bulgular}

Araştırma sonucunda elde edilen verilerin normal dağılıma uygunluğu incelenmiştir. Çalışma grubunda yer alan öğretmen adayı sayısı 50'den küçük olduğu için Shapiro-Wilk (Büyüköztürk, 2012) anlamlılık değerleri incelenerek $\mathrm{p}>, 05$ koşulunu sağlamadığ 1 için ön ve son test ( $\mathrm{p}=, 000$ : $\mathrm{p}<, 05)$ verilerinin normal dağılıma uygun olmadı̆̆ı anlaşılmıştır. Ayrıca ön test sonuçları için basıklık katsayısı $($,923) -1 ile +1 sınırları içinde olmasına rağmen çarpıklık katsayısı $(1,267)$-1 ile +1 sınırları dışında olduğu için verilerin normal dağılıma uygun olmadığı anlaşılmıştır. Son 
test sonuçları için ise çarpıklık katsayısı (-,451) -1 ile +1 sınırları içinde olmasına rağmen basıklık katsayısı (-1,096) -1 ile +1 sınırları dışında olduğu için verilerin normal dağılıma uygun olmadığı anlaşılmıştır. Veriler normal dağılıma uygun olmadığı için çalışma grubunun ön ve son test sonuçlarının istatistiksel olarak karşılaştırılmasında wilcoxon işaretli sıralar testi kullanılmıştır. Analiz sonucu tablo 2'de verilmiştir.

\section{Tablo 2}

Çalışma Grubunun Ön ve Son Test Puanlarına Ait Wilcoxon Işaretli Sıralar Testi Sonuçları

\begin{tabular}{lccccc}
\hline Son test-Ön test & N & Sıra Ortalaması & Sıra Toplami & z & p \\
\hline Negatif Sıralar & 4 & 7,38 & 29,50 & $-5,518$ & 0,000 \\
Pozitif Sıralar & 41 & 24,52 & 1005,50 & & \\
Eşit & 0 & & & & \\
\hline
\end{tabular}

Tablo 2 incelendiğinde ön test verileri ile son test verileri arasında istatistiksel olarak anlamlı bir farklılık görülmüştür $(\mathrm{z}=-5,518, \mathrm{p}<0,05)$. Fark puanlarının pozitif sıralar (son test) lehine olması tuzların hidrolizi konusunun öğretiminde kullanılan ATBÖ yaklaşımının öğrenme, kavram yanılgılarının belirlenmesi ve giderilmesi üzerinde anlamlı etkisinin olduğunu göstermektedir.

Öğretmen adaylarının çalışma kâğıtları Venville ve Dawson’un (2010) kullandıkları kriterlere uygun olarak değerlendirilmiş ve yapılan değerlendirmeler Tablo 3, 4 ve 5’te verilmiştir.

\section{Tablo 3}

Sodyum Asetat Tuzu için Öğretmen Adayları Tarafindan Üretilen Argümanların Seviyelerine Göre Frekans ve Yüzde Değerleri

\begin{tabular}{|c|c|c|c|c|c|}
\hline & & \multicolumn{2}{|c|}{ Ön Test } & \multicolumn{2}{|c|}{ Son Test } \\
\hline & & f & $\%$ & f & $\%$ \\
\hline \multirow[t]{4}{*}{ Doğru argüman } & Seviye 1 (İddia) & 7 & 15,6 & 6 & 13,3 \\
\hline & Seviye 2 (İddia, veri ve/ya da gerekçe) & 3 & 6,7 & 12 & 26,7 \\
\hline & Seviye 3 (İddia, veri/gerekçe ve destek ya da niteleyici) & - & - & - & - \\
\hline & Seviye 4 (İddia, veri/gerekçe, destek ve niteleyici) & 8 & 17,8 & 27 & 60,0 \\
\hline \multicolumn{2}{|l|}{ Tuzun türü yanlıș } & 18 & 40,0 & - & - \\
\hline \multicolumn{2}{|c|}{ Tuzun türü ile tuzu oluşturan asit ve bazın kuvvetli/zayıf olma durumu yanlış } & 6 & 13,3 & - & - \\
\hline \multicolumn{2}{|c|}{ Tuzun hidroliz denklemi yanlıs } & 2 & 4,4 & - & - \\
\hline \multicolumn{2}{|c|}{ Boş } & 1 & 2,2 & - & - \\
\hline \multicolumn{2}{|l|}{ Toplam } & 45 & 100,0 & 45 & 100,0 \\
\hline
\end{tabular}

Tablo 3 incelendiğinde ön testte sadece 8 fen bilgisi öğretmen adayının seviye 4, son testte ise yarısından fazlasının seviye 4'e uygun olacak şekilde argümanlar oluşturdukları, ön testte saptanan kavram yanılgılarının ise son testte tamamen giderildiği görülmektedir. Ön testte sodyum asetat için 18 öğretmen adayı bazik, 19 öğretmen adayı asidik, 5 öğretmen adayı ise nötr tuz cevabı verirken son testte tüm öğretmen adayları tuzun bazik olduğunu doğru olarak ifade etmiştir. 
Seviyelere göre değerlendirilen cevaplardan örnekler aşağıda sunulmuştur.

Seviye 1: "Sodyum asetat bazik bir tuzdur (iddia)."

Seviye 2: "Bazik tuzdur (iddia). Çünkü sodyum asetat tuzu sodyum hidroksit ile asetik asidin tepkimesi sonucunda oluşur (veri).”

Seviye 4: "Sodyum asetat bazik tuzdur (iddia). Baz olan sodyum hidroksit ile asit olan asetik asitten oluşur (veri). Kuvvetli baz ve zayıf asit vardır (gerekçe). Kuvvetli baz ve zayıf asitlerin tuzu bazik olur. Su ile verdiği hidroliz tepkimesinde (Şekil 1) ise sodyum iyonu su ile hidroliz tepkimesi vermezken asetat iyonu su ile hidroliz tepkimesi vererek asetik asit ve hidroksil iyonu oluşturur. Ortamda hidroksil iyonu olduğu için bu tuz baziktir (destek-niteleyici)”.

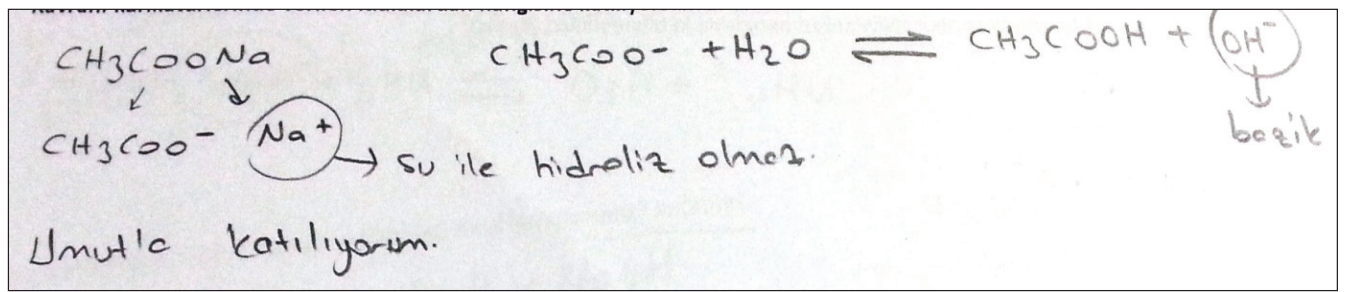

Şekil I. Sodyum asetat tuzu için yazılan hidroliz tepkimesi

Bir öğretmen adayı tarafından sodyum asetat tuzu için oluşturulan bir argüman örneği şekil 2’de görülmektedir.

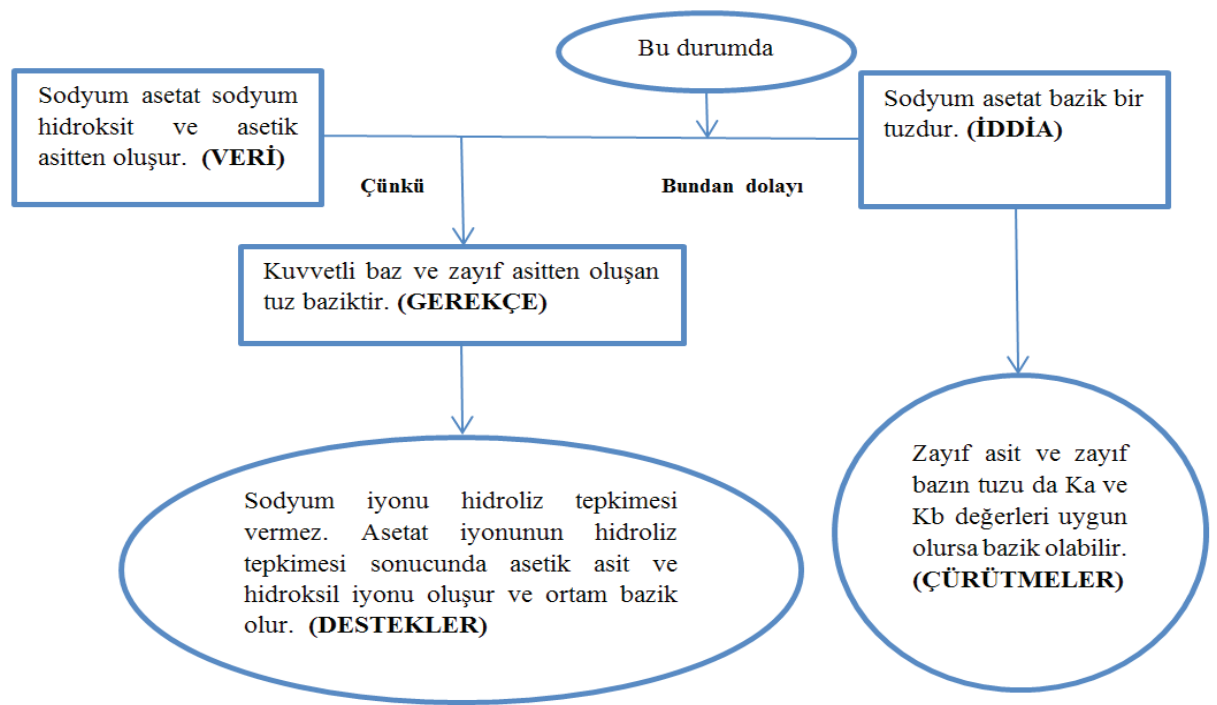

Şekil 2. Sodyum asetat tuzu için oluşturulan argüman 
Tuzların hidrolizi konusunun öğretiminde argümantasyon tabanlı bilim öğrenme (atbö) yaklaşımının etkisi

\section{Tablo 4}

Kalsiyum Nitrat Tuzu için Öğretmen Adayları Tarafından Üretilen Argümanların Seviyelerine Göre Frekans ve Yüzde Değerleri

\begin{tabular}{llcccc}
\hline & & \multicolumn{2}{c}{ Ön Test } & \multicolumn{2}{c}{ Son Test } \\
\cline { 2 - 5 } & & $\mathbf{f}$ & $\%$ & $\mathbf{f}$ & \% \\
\hline \multirow{2}{*}{ Doğru argüman } & Seviye 1 (İddia) & 13 & 28,9 & 9 & 20,0 \\
\cline { 2 - 6 } & Seviye 2 (İddia, veri ve/ya da gerekçe) & 5 & 11,1 & 20 & 44,4 \\
\cline { 2 - 6 } & Seviye 3 (İddia, veri/gerekçe ve destek ya da niteleyici) & - & - & - & - \\
\cline { 2 - 6 } & Seviye 4 (İddia, veri/gerekçe, destek ve niteleyici) & - & - & 13 & 28,9 \\
\hline Tuzun türü yanlış & & 15 & 33,3 & - & - \\
\hline Tuzun türü ile tuzu oluşturan asit ve bazın kuvvetli/zayılf olma durumu yanlış & 3 & 6,7 & 2 & 4,4 \\
\hline Tuzun hidroliz denklemi yanlıș & 2 & 4,4 & 1 & 2,2 \\
\hline Boş & 7 & 15,6 & - & - \\
\hline Toplam & $\mathbf{4 5}$ & $\mathbf{1 0 0 , 0}$ & $\mathbf{4 5}$ & $\mathbf{1 0 0 , 0}$ \\
\hline
\end{tabular}

Tablo 4 incelendiğinde fen bilgisi öğretmen adaylarının ön testte daha çok seviye 1, son testte ise çoğunluğunun seviye 2, sadece 13 öğretmen adayının ise seviye 4'e uygun argümanlar oluşturdukları, ön testte saptanan kavram yanılgılarının büyük oranda giderildiği görülmektedir. Ön testte kalsiyum nitrat için 18 öğretmen adayı nötr, 11 öğretmen adayı bazik, 7 öğretmen adayı asidik cevabı vermiştir. Son testte ise öğretmen adaylarının tamamına yakını tuzun nötr olduğunu doğru olarak ifade edebilmiştir.

Seviyelere göre değerlendirilen cevaplardan örnekler aşağıda sunulmuştur.

Seviye 1: "Kalsiyum nitrat nötr bir tuzdur" (iddia).

Seviye 2: "Nötr tuzdur (iddia). Çünkü kalsiyum nitrat tuzu kalsiyum hidroksit ve nitrik asit tepkimesi sonucu oluşur (veri)."

Seviye 4: "Kalsiyum nitrat nötr bir tuzdur (iddia). Kalsiyum hidroksit ve nitrik asit içerir (veri). Baz kalsiyum hidroksit kuvvetlidir. Asit nitrik asit kuvvetlidir (gerekçe). Kuvvetli asit ve kuvvetli bazın tuzu nötr olur. Kalsiyum ve nitrat iyonları su ile hidroliz tepkimesi (Şekil 3) vermez (destekniteleyici)."

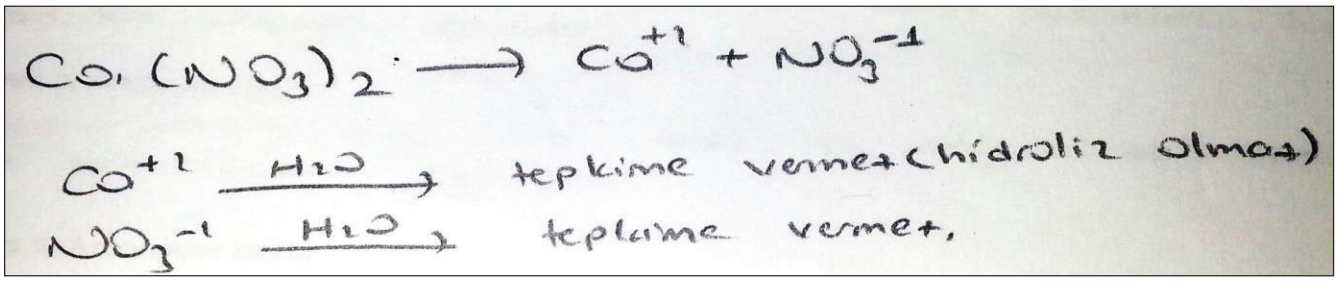

Şekil 3. Kalsiyum nitrat tuzu için yazılan hidroliz tepkimesi 
Bir öğretmen adayı tarafından kalsiyum nitrat tuzu için oluşturulan bir argüman örneği şekil 4'de görülmektedir.

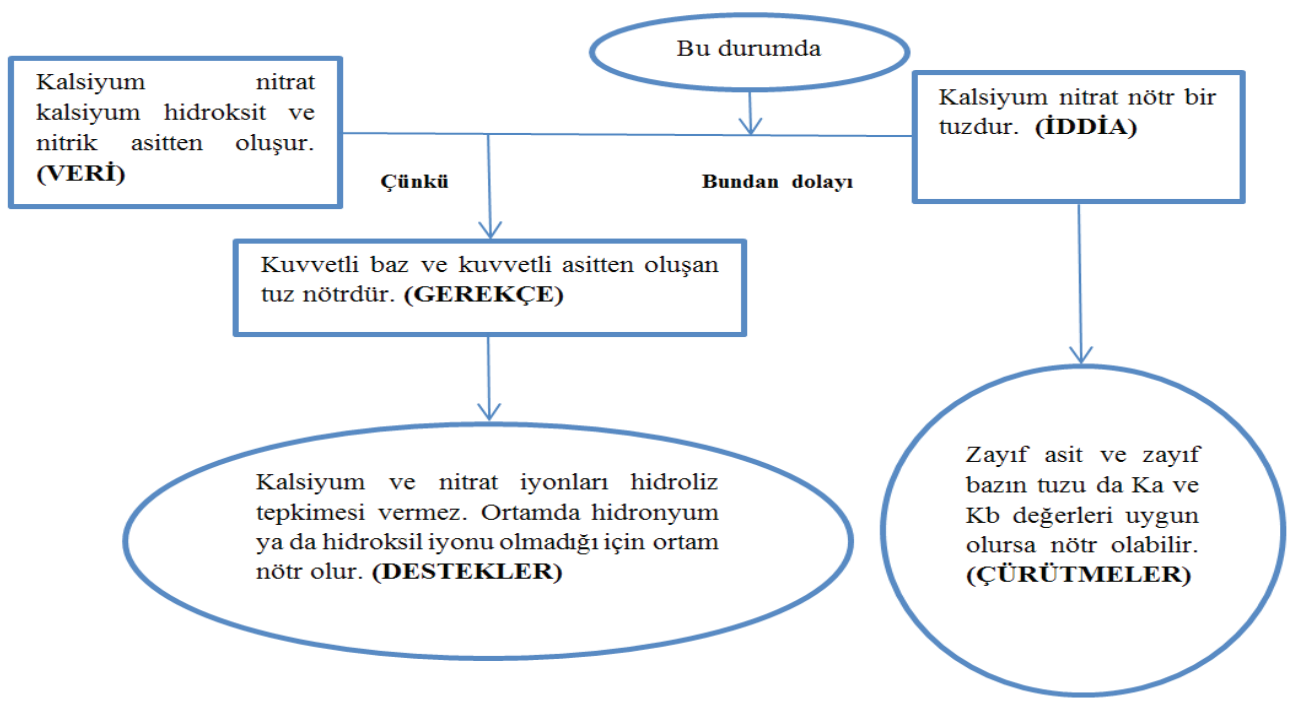

Şekil 4. Kalsiyum nitrat tuzu için oluşturulan argüman

Tablo 5

Amonyum Klorür Tuzu için Öğretmen Adayları Tarafindan Üretilen Argümanların Seviyelerine Göre Frekans ve Yüzde Değerleri

\begin{tabular}{llcccc}
\hline & & \multicolumn{2}{c}{ Ön Test } & \multicolumn{2}{c}{ Son Test } \\
\cline { 2 - 6 } & & $\mathbf{f}$ & $\mathbf{0}$ & $\mathbf{f}$ & $\%$ \\
\hline \multirow{2}{*}{ Doğru argüman } & Seviye 1 (İddia) & 10 & 22,2 & 6 & 13,3 \\
\cline { 2 - 6 } & Seviye 2 (İddia, veri ve/ya da gerekçe) & 4 & 8,9 & 11 & 24,4 \\
\cline { 2 - 6 } & Seviye 3 (İddia, veri/gerekçe ve destek ya da niteleyici) & - & - & - & - \\
\cline { 2 - 6 } & Seviye 4 (İddia, veri/gerekçe, destek ve niteleyici) & 5 & 11,1 & 26 & 57,8 \\
\hline Tuzun türü yanlış & & 14 & 31,1 & - & - \\
\hline Tuzun türü ile tuzu oluşturan asit ve bazın kuvvetli/zayıf olma durumu yanlış & 5 & 11,1 & 2 & 4,4 \\
\hline Tuzun hidroliz denklemi yanlış & 3 & 6,7 & - & - \\
\hline Boş & 4 & 8,9 & - & - \\
\hline Toplam & $\mathbf{4 5}$ & $\mathbf{1 0 0 , 0}$ & $\mathbf{4 5}$ & $\mathbf{1 0 0 , 0}$ \\
\hline
\end{tabular}

Tablo 5 incelendiğinde fen bilgisi öğretmen adaylarının ön testte daha çok seviye 1, son testte ise çoğunluğunun seviye 4, bir kısmının ise seviye 2 için uygun olan argümanlar oluşturdukları, ön testte saptanan kavram yanılgılarının büyük oranda giderildiği görülmektedir. Ön testte amonyum klorür için 19 öğretmen adayı asidik, 7 öğretmen adayı nötr, 12 öğretmen adayı bazik 
cevabı vermiştir. Son testte ise öğretmen adaylarının tamamına yakını tuzun asidik olduğunu doğru olarak belirtmiştir.

Seviyelere göre değerlendirilen cevaplardan örnekler aşağıda sunulmuştur.

Seviye 1: "Amonyum klorür asidik bir tuzdur (iddia)."

Seviye 2: "Asidik tuz (iddia) çünkü amonyak ile hidroklorik asitten oluşur (veri)."

Seviye 4: "Asidik tuzdur (iddia). Zayıf baz olan amonyak ile kuvvetli asit olan hidroklorik asitten oluşur (veri-gerekçe). Kuvvetli asit ve zayıf baz olduğu için asidiktir. Klor iyonu su ile hidroliz tepkimesi (Şekil 5) vermez. Amonyum iyonu ise verir ve amonyak ile hidronyum iyonu açı̆̆a çıkar. Ortam asidik olur (destek-niteleyici)."

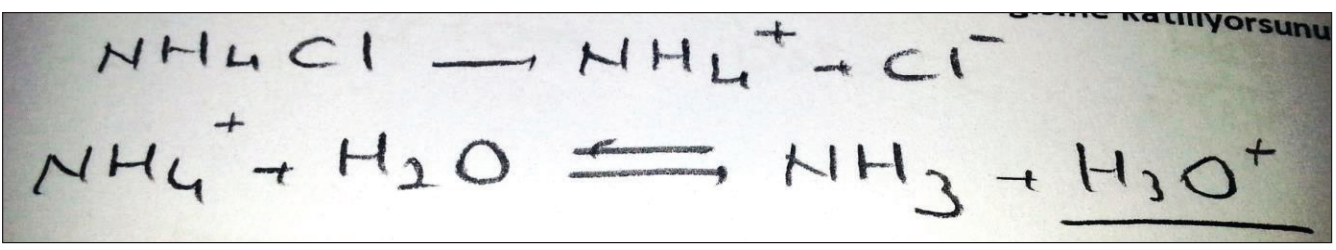

Şekil 5. Amonyum klorür tuzu için yazılan hidroliz tepkimesi

Bir öğretmen adayı tarafından amonyum klorür tuzu için oluşturulan bir argüman örneği şekil 6'da görülmektedir.

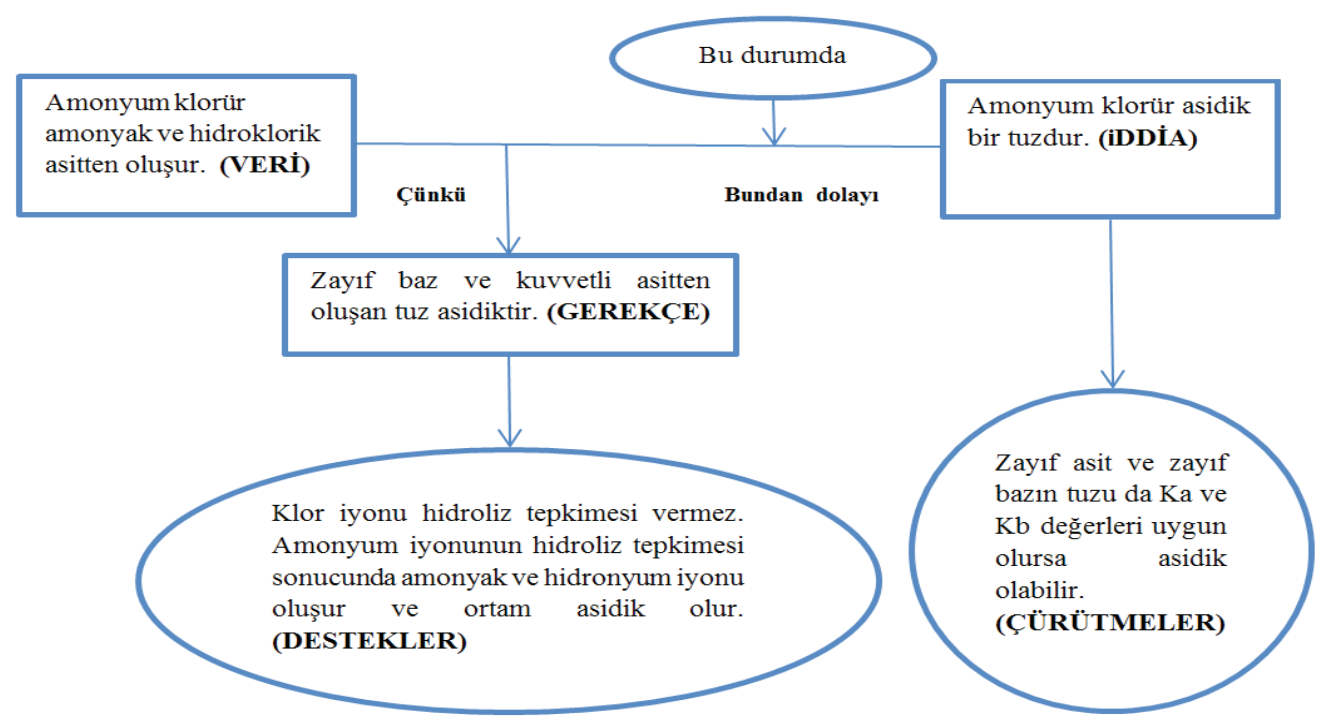

Şekil 6. Amonyum klorür tuzu için oluşturulan argüman 
Gönüllü olan 17 öğretmen adayı ile ATBÖ yaklaşımına yönelik düşüncelerini saptamak amacı ile görüşme yapılmış ve görüşmeden elde edilen bulgular Tablo 6’da ifade edilmiştir.

Tablo 6

Öğretmen adaylarının ATBÖ Yaklaşımına Yönelik Düşüncelerine ait Frekans Değerleri

\begin{tabular}{|c|c|c|c|}
\hline & & & $\mathbf{f}$ \\
\hline \multirow[t]{11}{*}{ Olumlu düşünceler } & \multirow[t]{2}{*}{ Ön bilgiler } & Yeni öğrenilen bilgilerle karşılaştırılması & 7 \\
\hline & & Açı̆̆a çıkarılması & 1 \\
\hline & \multirow[t]{4}{*}{ Öğrenme } & Anlamli & 9 \\
\hline & & Kalıc1 & 7 \\
\hline & & Kolay & 2 \\
\hline & & Eğlenceli & 1 \\
\hline & \multirow[t]{2}{*}{ Grup etkinlikleri } & Tartışma & 2 \\
\hline & & Fikir alışverişi & 2 \\
\hline & \multirow[t]{2}{*}{ Rapor yazma } & Deneyi yaparken eş zamanlı olarak aşama aşama yazma & 8 \\
\hline & & Bilinçli yazma & 3 \\
\hline & Deney yapma & Farkında olarak yapma & 1 \\
\hline \multirow[t]{2}{*}{ Olumsuz düşünceler } & \multicolumn{2}{|c|}{ Uzun zaman alması } & 4 \\
\hline & \multicolumn{2}{|c|}{ Zor deneylerde uygulanmasının güç olması } & 1 \\
\hline
\end{tabular}

Az sayıda öğretmen adayı uygulamanın uzun zaman aldığını ve zor deneylerde uygulanmasının güç olduğunu ifade etse de genel olarak öğretmen adaylarının ATBÖ yaklaşımına yönelik düşüncelerinin ön bilgiler, öğrenme, grup etkinlikleri, rapor yazma ve deney yapma bağlamında yapılandığg ve olumlu olduğu saptanmıştır. Görüşme yapılan öğretmen adaylarının ön test puanı son test puanından yüksek olanlar ile orta ve yüksek başarı gösterenlerden oluştukları görülmüştür.

\section{Tartışma, Sonuç ve Öneriler}

Araştırma sonucunda ön test sonuçları ile son test sonuçları arasında fark puanlarının sıra ortalaması ve toplamları dikkate alındığında pozitif sıralar yani son test lehine anlamlı bir farklılık olduğu saptanmıştır. Ön-son testten elde edilen sonuçlar doğrultusunda bu yaklaşımın öğrenme üzerinde etkili olduğu anlaşılmıştır. Benzer şekilde alanyazında da argümantasyona dayalı uygulamaların öğrenme (Çetin, 2014; Kaya, 2013; McNeill ve Knight, 2013; Newton vd., 1999; Osborne vd., 2004; Tümay ve Köseoğlu, 2011) üzerinde olumlu etkileri olduğu ortaya koyulmuştur.

Araştırma sonucunda ATBÖ yaklaşımının kavram yanılgılarının belirlenmesi ve giderilmesi üzerinde etkili olduğu saptanmıştır. Öyle ki, tuzun türü, tuzu oluşturan asit ve bazın kuvvetli/ zayıf olma özelliği ve tuzun hidroliz tepkimesi ile ilgili olarak ön testte saptanan kavram yanılgılarının son testte sodyum asetat için tamamen, kalsiyum nitrat ve amonyum klorür için 
büyük oranda giderildiği saptanmıştır. Benzer şekilde argümantasyona dayalı uygulamaların kavram yanılgılarının giderilmesi üzerinde etkili olduğu ifade edilmektedir (Alexopoulou ve Driver, 1996; Bell ve Linn, 2000; Yeşiloğlu, 2007).

ATBÖ yaklaşımının öğretmen adaylarının daha nitelikli argümanlar oluşturabilmeleri üzerinde de olumlu etkileri olduğu görülmüştür. Öyle ki, ön testte az sayıda öğretmen adayı sodyum asetat ve amonyum klorür için seviye 4'e uygun argümanlar oluştururken son testte sodyum asetat, kalsiyum nitrat ve amonyum klorür için iddia, veri/gerekçe, destek ve niteleyici içerecek şekilde seviye 4'e uygun argüman oluşturan öğretmen adayı sayısında artış olduğu görülmüştür. Benzer şekilde Zohar ve Nemet (2002) tarafından yapılan çalışmada da argümantasyon temelli etkinliklere katılan öğrencilerin ürettikleri argümanların başlangıç için temel seviyede olduğu ancak süreç içerisinde öğrencilerin argüman oluşturma becerilerinin gelişerek daha üst seviyelere ulaştığg sonucuna ulaşılmıştır.

Genel olarak öğretmen adaylarının ATBÖ yaklaşımına yönelik düşüncelerinin olumlu olduğu ve öğretmen adaylarının olumlu düşüncelerini ön bilgileri açı̆̆a çıkarma ve yeni öğrenilen bilgilerle karşılaştırma; anlamlı, kalıcı, kolay ve eğlenceli öğrenmeyi sağlama; tartışma ve fikir alışverileri ile gerçekleştirilen grup etkinliklerine katılım; raporu deneyi yaparken eş zamanlı olarak aşama aşama ve bilinçli bir şekilde yazma ve deneyi farkında olarak yapma şeklinde ifade ettikleri belirlenmiştir. Bu araştırmada fen bilgisi öğretmen adaylarının ATBÖ’nün rapor yazma üzerindeki olumlu etkilerini belirtmiş olmaları alanyazınla da uyum göstermektedir (Demirbağ ve Günel, 2014). Az sayıda öğretmen adayının ise uygulamanın uzun zaman aldığını ve zor deneylerde uygulanmasının güç olduğunu düşündüğü saptanmıştır.

ATBÖ yaklaşımının öğrenme, kavram yanılgılarının belirlenmesi ve giderilmesi olmak üzere bilişsel; öğretmen adaylarının yaklaşıma yönelik düşüncelerinin olumlu olması bağlamında duyuşsal ve tüm öğretmen adaylarının aktivitelere hem bireysel hem de grup üyeleri ile etkileşim halinde çalışarak aktif bir şekilde katılmalarını sağlama açısından devinişsel olmak üzere çok yönlü oluşturduğu olumlu etkilerin yanı sıra fen bilimleri derslerinin araştırma-sorgulama temelli etkinliklere dayalı yürütülmesi gerektiği düşünüldügünde yaygın bir şekilde kullanılmasının gerekli olduğu düşünülmektedir. 


\section{Kaynaklar}

Akar, S., Erkol, M., Kabataş, E., Büyükkasap, E., Günel, M. (2007, August). How did pre-service science teachers ideas toward laboratory activities changed after using the science writing heuristic student template? ESERA Conference, Malmö University, Malmö, Sweden.

Akkus, R., Gunel, M., Hand, B. (2007). Comparing an inquiry-based approach known as the science writing heuristic to traditional science teaching practices: Are there differences? International Journal of Science Education, 29(14), 1745-1765, doi: 10.1080/09500690601075629

Alexopoulou, E., Driver, R. (1996). Small-group discussion in physics: Peer interaction modes in pairs and fours. Journal of Research in Science Teaching, 33(10), 1099-1114, doi: 10.1002/(SICI)10982736(199612)33:10<1099::AID-TEA4>3.0.CO;2-N

Bell, P., Linn, M. C. (2000). Scientific arguments as learning artifacts: Designing for learning from the web with KIE. International Journal of Science Education, 22(8), 797-817, doi: 10.1080/095006900412284

Büyüköztürk, Ş. (2012). Sosyal bilimler için veri analizi el kitabı: İstatistik, araştırma deseni SPSS uygulamaları ve yorum. (16. Baskı). Ankara: Pegem A Akademi.

Cavagnetto, A. R. (2010). Argument to foster scientific literacy: A review of argument interventions in K-12 science contexts. Review of Educational Research, 80(3), 336-371, doi: 10.3102/0034654310376953

Ceylan, Ç. (2010). Fen laboratuvar etkinliklerinde argümantasyon tabanlı bilim öğrenme-atbö yaklaşımı. (Yayınlanmamış yüksek lisans tezi). Gazi Üniversitesi, Eğitim Bilimleri Enstitüsü, Ankara.

Çetin, P. S. (2014). Explicit argumentation instruction to facilitate conceptual understanding and argumentation skills. Research in Science \& Technological Education, 32(1), 1-20, doi: 10.1080/02635143.2013.850071

Çinici, A., Özden, M., Akgün, A., Herdem, K., Karabiber, H. L., Deniz, Ş. M. (2014). Kavram karikatürleriyle desteklenmiş argümantasyon temelli uygulamaların etkinliğinin incelenmesi. Adıyaman Üniversitesi Sosyal Bilimler Enstitüsü Dergisi, 7(18), 571-596. http://dergipark.ulakbim.gov.tr/ adyusbd/article/view/5000071172/5000065627 adresinden alınmıştır.

Demirbağ, M., Günel, M. (2014). Argümantasyon tabanlı fen eğitimi sürecine modsal betimleme entegrasyonunun akademik başarı, argüman kurma ve yazma becerilerine etkisi. Kuram ve Uygulamada Eğitim Bilimleri, 14(1), 373-392. http://www.kuyeb.com/pdf/ tr/976cb428ad157b2856f83aa8a1eb544eneltr.pdf adresinden alınmıştır.

Deveci, A. (2009). İlköğretim yedinci sınıf öğrencilerinin maddenin yapısı konusunda sosyobilimsel argümantasyon, bilgi seviyeleri ve bilişsel düşünme becerilerini geliştirmek. (Yayınlanmamış yüksek lisans tezi). Marmara Üniversitesi, Eğitim Bilimleri Enstitüsü, İstanbul.

Driver, R., Newton, P., Osborne, J. (2000). Establishing the norms of scientific argumentation in classrooms. Science Education, 84(3), 287-312, doi: 10.1002/(SICI)1098-237X(200005)84:3<287::AIDSCE1>3.0.CO;2-A

Duschl, R. A., Osborne, J. (2002). Supporting and promoting argumentation discourse in science education. Studies in Science Education, 38, 39-72, doi: 10.1080/03057260208560187

Grimberg, B. I., Hand, B. M. (2003, March). The impact of a scientific writing approach in high school students' learning. Paper presented at the National Association for Research in Science Teaching, Philadelphia, PA.

Günel, M., Kabataş-Memiş, E., Büyükkasap, E. (2010). Effects of the science writing heuristic approach on primary school students' science achievement and attitude toward science course. Education and Science, 35(155), 49-62. http://egitimvebilim.ted.org.tr/index.php/EB/article/viewFile/560/48 adresinden alınmıştır. 
Tuzların hidrolizi konusunun öğretiminde argümantasyon tabanlı bilim öğrenme (atbö) yaklaşımının etkisi

Hand, B., Wallace, C. W., Yang, E. M. (2004). Using a Science Writing Heuristic to enhance learning outcomes from laboratory activities in seventh-grade science: Quantitative and qualitative aspects. International Journal of Science Education, 26(2), 131-149, doi: 10.1080/0950069032000070252

Hand, B., Choi, A. (2010). Examining the impact of student use of multiple modal representations in constructing arguments in organic chemistry laboratory classes. Research in Science Education, 40(1), 29-44, doi: 10.1007/s11165-009-9155-8

Hohenshell, L. M., Hand, B. (2006). Writing-to-learn strategies in secondary school cell biology: A mixed method study. International Journal of Science Education, 28(2-3), 261-289, doi: $10.1080 / 09500690500336965$

Kabataş-Memiş, E., Günel M., Büyükkasap E. (2009, Ekim). Isı ünitesinin ilköğretim 6. Sinıf seviyesi ögretiminde yaparak yazarak bilim öğrenimi- YYBÖ yaklaşımının kullanılmasının öğrenci akademik başarı ve tutumuna etkisi. 18. Ulusal Eğitim Bilimleri Kurultayı, Ege Üniversitesi, İzmir.

Kabataş-Memiş, E. (2014). İlköğretim öğrencilerinin argümantasyon tabanlı bilim öğrenme yaklaşımı uygulamalarına ilişkin görüşleri. Kastamonu Eğitim Dergisi, 22(2), 401-418. http://79.123.169.199/ ojs/index.php/Kefdergi/article/view/179/111 adresinden alınmıştır.

Kaya, E. (2013). Argumentation practices in classroom: pre-service teachers' conceptual understanding of chemical equilibrium. International Journal of Science Education, 35(7), 1139-1158, doi: 10.1080/09500693.2013.770935

Keys, C. W., Hand, B., Prain, V., Collins, S. (1999). Using the science writing heuristic as a tool for learning from laboratory investigations in secondary science. Journal of Research in Science Teaching, 36(10), 1065-1084, doi: 10.1002/(SICI)1098-2736(199912)36:10<1065::AID-TEA2>3.0.CO;2-I

Khishfe, R. (2014). Explicit nature of science and argumentation instruction in the context of socioscientific issues: An effect on student learning and transfer. International Journal of Science Education, 36(6), 974-1016, doi: 10.1080/09500693.2013.832004

Kıngır, S., Geban, Ö., Günel, M. (2011). Öğrencilerin kimya derslerinde argümantasyon tabanlı bilim öğrenme yaklaşımının uygulanmasına ilişkin görüşleri. Ahmet Keleşoğlu Eğitim Fakültesi Dergisi, 32, 15-28. http://www.ide.konya.edu.tr/egtfakdergi/Sayilar/sayi32/02.pdf adresinden alınmıştır.

Köseoğlu, F, Tümay, H., Budak, E. (2008). Bilimin doğası hakkında paradigma değişimleri ve öğretimi ile ilgili yeni anlayışlar. GÜ, Gazi Eğitim Fakültesi Dergisi, 28(2), 221-237. http://egitim.erciyes.edu. tr/ imarulcu/Bilimtarihi/paradigma_degisimleri.pdf adresinden alınmıştır.

Lawson, A. (2003). The nature and development of hypothetico-predictive argumentation with implications for science teaching. International Journal of Science Education, 25(11), 1387-1408, doi: $10.1080 / 0950069032000052117$

McNeill, K. L., Pimentel, D. S. (2010). Scientific discourse in three urban classrooms: The role of the teacher in engaging high school students in argumentation. Science Education, 94(2), 203-229, doi: $10.1002 /$ sce. 20364

McNeill, K. L. (2011). Elementary students' views of explanation, argumentation and evidence, and their abilities to construct arguments over the school year. Journal of Research in Science Teaching, 48(7), 793-823, doi: 10.1002/tea.20430

McNeill, K. L., Knight, A. M. (2013). Teachers'pedagogical content knowledge of scientific argumentation: The impact of professional development on K-12 teachers. Science Education, 97(6), 936-972, doi: $10.1002 /$ sce. 21081

Newton, P., Driver, R., Osborne, J. (1999). The place of argumentation in the pedagogy of school science. International Journal of Science Education, 21(5), 553-576, doi: 10.1080/095006999290570 
Norris, S. P., Phillips, L. M. (2003). How literacy in its fundamental sense is central to scientific literacy. Science Education, 87(2), 224-240, doi: 10.1002/sce.10066

Osborne, J., Erduran, S., Simon, S. (2004). Enhancing the quality of argumentation in school science. Journal of Research in Science Teaching, 41(10), 994-1020, doi: 10.1002/tea.20035

Öğreten, B., Uluçınar-Sağır, Ş. (2014). Argümantasyona dayalı fen öğretiminin etkililiğinin incelenmesi. Türk Fen Eğitimi Dergisi, 11(1), 75-100. http://docplayer.biz.tr/10415807-Argumantasyona-dayalifen-ogretiminin-etkililiginin-incelenmesi.html adresinden alınmıştır.

Toulmin, S. (1958). The uses of argument. Cambridge, UK: Cambridge University Press.

Türkoğuz, S., Cin, M. (2013). Argümantasyona dayalı kavram karikatürü etkinliklerinin öğrencilerin kavramsal anlama düzeylerine etkisi. Buca Eğitim Fakültesi Dergisi, 35, 155-173. http://www. befjournal.com.tr/index.php/dergi/article/view/604/pdf_176 adresinden alınmıştır.

Tümay, H., Köseoğlu, F. (2011). Kimya öğretmen adaylarının argümantasyon odaklı öğretim konusunda anlayıșlarının geliștirilmesi. Türk Fen Eğitimi Dergisi, 8(3), 105-119. http://www.tused.org/ internet/tused/archive/v8/i3/text/tusedv8i3s8.pdf adresinden alınmıştır.

Uluçınar-Sağır, Ş., Kılıç, Z. (2013). İlköğretim öğrencilerinin bilimin doğasını anlama düzeylerine bilimsel tartışma odaklı öğretimin etkisi. Hacettepe Üniversitesi Eğitim Fakültesi Dergisi, 44, 308-318. http:// dergipark.ulakbim.gov.tr/hunefd/article/view/5000048178/5000045498 adresinden alınmıştır.

Üstünkaya, I., Savran-Gencer, A. (2012, Haziran). İlköğretim 6. sinıf seviyesinde bilimsel tartışma (argumentation) odakl etkinliklerle dolaşım sistemi konusunun öğretiminin akademik başarıya etkisi. X. Ulusal Fen Bilimleri ve Matematik Eğitimi Kongresi, Niğde.

Venville, G. J., Dawson, V. M. (2010). The impact of a classroom intervention on grade 10 students' argumentation skills, informal reasoning, and conceptual understanding of science. Journal of Research in Science Teaching, 47(8), 952-977, doi: 10.1002/tea.20358

Yeşildağ-Hasançebi, F., Günel, M. (2013). Argümantasyon tabanlı bilim öğrenme yaklaşımının dezavantajlı öğrencilerin fen bilgisi başarılarına etkisi. İlköğretim Online, 12(4), 1056-1073. http://ilkogretimonline.org.tr/vol12say4/v12s4m11.pdf adresinden alınmıştır.

Yeşiloğlu, S. N. (2007). Bilimsel tartışma (argümantasyon) yöntemi ile gazlar konusunun lise öğrencilerine öğretimi. (Yayınlanmamış yüksek lisans tezi). Gazi Üniversitesi Eğitim Bilimleri Enstitüsü, Ankara.

Zohar, A., Nemet, F. (2002). Fostering students' knowledge and argumentation skills through dilemmas in human genetics. Journal of Research in Science Teaching, 39(1), 35-62, doi: 10.1002/tea.10008 